\title{
THE MECHANICS BEHIND FORMATION OF SECONDARY LEDEBURITE DURING TOOL STEEL WELDING
}

\author{
Marica Prijanovič Tonkovič, Aleš Nagode, Borut Kosec, Ivan Samardžić, Blaž Karpe, Ladislav Kosec
}

Original scientific paper In this article we describe the microstructural changes in the heat affected zone (HAZ) of the tool steel W. Nr. 1.2379, which was surfaced or welded by the submerged arc welding technique (SAW) with different welding parameters. Microstructure of the welds and of the surfacing welds was analysed by optical and scanning electron microscope. In this research, we particularly studied microstructural changes in the area of primary chromium carbides in the HAZ and their effect on the weld crystalization. We came to the conclusion that the temperature in the HAZ is high enough during the welding process that it caused primary carbides to dissolve and concentration of the carbide-forming elements and carbon increased in the surrounding austenite matrix area to eutectic composition, which remelts and solidified as secondary eutectic (ledeburite).

Keywords: carbides dissolution; crystallization; heat affected zone (HAZ); secondary ledeburite; submerged arc welding; weld

Mehanika pri formiranju sekundarnog ledeburita tijekom zavarivanja alatnog čelika

Izvorni znanstveni članak U ovom prilogu opisujemo mikrostrukturne promjene u zoni toplinskog utjecaja (ZTU) alatnog čelika W. Nr. 1.2379, koji je bio navaren ili zavaren po postupku zavarivanja pod praškom s različitim parametrima zavarivanja. Mikrostrukturu zavara i navara analizirali smo pomoću optičnog i rasterskog (skenirajućeg) elektronskog mikroskopa. U analiziranju smo posebno utvrđivali mikrostrukturne promjene u okolini primarnih kromovih karbida u zoni toplinskog utjecaja i njihov utjecaj na kristalizaciju zavara. Utvrdili smo, da su temperature u zoni toplinskog utjecaja za vrijeme zavarivanja dovoljno visoke da se za vrijeme rastapanja primarnih karbida u okolnoj matici do te mjere povećala koncentracija karbidotvornih elemenata i ugljika, da je nastala tz. talina eutektičnog sastava, koja se stvrdnula u sekundarni eutektik (ledeburit), na kojemu se na granici ZTU/zavara pokrene kristalizacija zavara.

Ključneriječi: karbidi; taljenje; kristalizacija; sekundarni ledeburit; zavar; zavarivanje pod praškom; zona toplinskog utjecaja (ZTU)

\section{Introduction}

Besides chemical composition of the base and filler material, welding technique has also an effect on the the weld and surfacing weld quality. Because of different input of heat energy during welding, the width of the heat affected zone (HAZ) varies. These occurances in the HAZ are an important segment of knowledge and awareness of metallurgical processes connected with heating and cooling of the base material $[1,2]$.

In submerged arc welding technique, electric arc is covered with welding powder, which melts and forms a slag, which covers, protects as well as forms the top of the weld $[3,4]$. During the welding process, welding parameters are essential. It is known that in the case of too powerfull current, the gas remains in the weld and causes occurance of cracks.

Tool steels are not easily surfaced or welded [5] because they tend to crack and need to be preheated and slowly cooled after welding. In our case we did not preheat the steel since we were only interested in the microstructure in the HAZ. For the base material we used chromium ledeburitic tool steel OCR12 VM (W. Nr. 1.2379) [6]. The goal of this research was to find out what kind of microstructure occurs after the submerged arc welding in the weld zone and in the HAZ, and what is happening with primary eutectic carbides.

\section{Tests description}

We made four different specimens for our research by welding two V-joint welds and two surfacing welds. Chemical composition of workpieces and filler material is shown in Tab. 1. Welding was carried out on the welding device for submerged arc welding by Iskra manufacturer.
Dimensions of the weld are visible in Fig. 1a. The welding pass sequence was carried out in three steps: first weld bead layer (1), followed by welding the weld face (2), and final welding of the weld root (3). Fig. 1c shows the photo of the workpiece.

Table 1Chemical composition of steel base and filler material

\begin{tabular}{|c|c|c|c|c|c|c|c|c|}
\hline \begin{tabular}{c} 
Type of \\
material \\
\cline { 2 - 9 } \\
$\begin{array}{c}\text { SIST EN } \\
10027-2\end{array}$
\end{tabular} & $\mathrm{C}$ & $\mathrm{Si}$ & $\mathrm{Mn}$ & $\mathrm{P}$ & $\mathrm{S}$ & $\mathrm{Cr}$ & $\mathrm{Mo}$ & $\mathrm{V}$ \\
\hline $\begin{array}{c}\text { Workpiece: } \\
1.2379\end{array}$ & 1,50 & 0,4 & 0,4 & 0,03 & 0,03 & 11,5 & 0,8 & 0,85 \\
\hline $\begin{array}{c}\text { Filler } \\
\text { material: } \\
\text { Filtubdur } \\
112\end{array}$ & 0,08 & 0,35 & 1,4 & $/$ & 0,03 & 5,0 & 0,85 & $/$ \\
\hline
\end{tabular}

a)
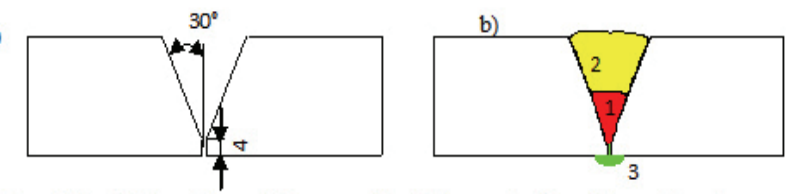

1-welding first bead, 2 -wel ding second bead, 3 - penetration of the weld root

c)

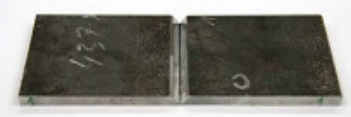

Figure1Making the specimens: a) groove weld preparation, b) welding pass sequnce,c) fotograph of workpieces before welding

Besides filler and base material we used basic powder [7], which is used for automatic welding and surfacing of ordinary structural as well as fine-grained steels up to yield stress of $430 \mathrm{~N} / \mathrm{mm}^{2}$. 
Tab. 2 shows welding parameters of various specimens. Two modes of welding parameters were set for $\mathrm{V}$-joint and two for surfacing welding method.

Table2Welding parameters

\begin{tabular}{|c|c|c|c|c|}
\hline Specimen & 1-weld & 2-weld & $\begin{array}{c}\text { 3-surfacing } \\
\text { weld }\end{array}$ & $\begin{array}{c}4 \text {-surfacing } \\
\text { weld }\end{array}$ \\
\hline $\begin{array}{c}\text { Diameter of wire } \\
(\mathrm{mm})\end{array}$ & 3,2 & 3,2 & 3,2 & 3,2 \\
\hline Voltage (V) & 28 & 27 & 28 & 29 \\
\hline Current (A) & 470 & 610 & 628 & 450 \\
\hline $\begin{array}{c}\text { Weld length } l_{1} \\
\text { (mm) }\end{array}$ & 151 & 161 & 88 & 87,3 \\
\hline Weld time, $t(\mathrm{~s})$ & 37,3 & 36,51 & 9,81 & 9,5 \\
\hline $\begin{array}{c}\text { Welding speed, } v \\
\text { (cm/min) }\end{array}$ & 72,03 & 79,37 & 57,75 & 55,13 \\
\hline $\begin{array}{c}\text { Energy input, } E \\
(\mathrm{~kJ} / \mathrm{cm})\end{array}$ & 10,96 & 12,45 & 18,26 & 14,20 \\
\hline
\end{tabular}

Welding speed has been calculated through the measurement of welding time and length Eq. (1).

$v=\frac{3 \cdot l_{1} \cdot 60}{t}$.

Input of energy has been calculated with Eq. (2).

$E=\frac{I \cdot U}{v}$

Fig. 2 shows the profile of hardness across the base/HAZ interface. Base material had hardness from 206 to $231 \mathrm{HV}$. In the cold part of the HAZ (i.e. part on the border with the base material) the hardness steeply increases. In the hot part of the HAZ hardness decreases again, especially at the border of HAZ/weld. Hardness depends on the current and on the type of welding. Surfacing welds have higher values of hardness than the V-joint welds. Fig.2 shows that higher current (specimen 2) means lower values of hardness and vice versa.

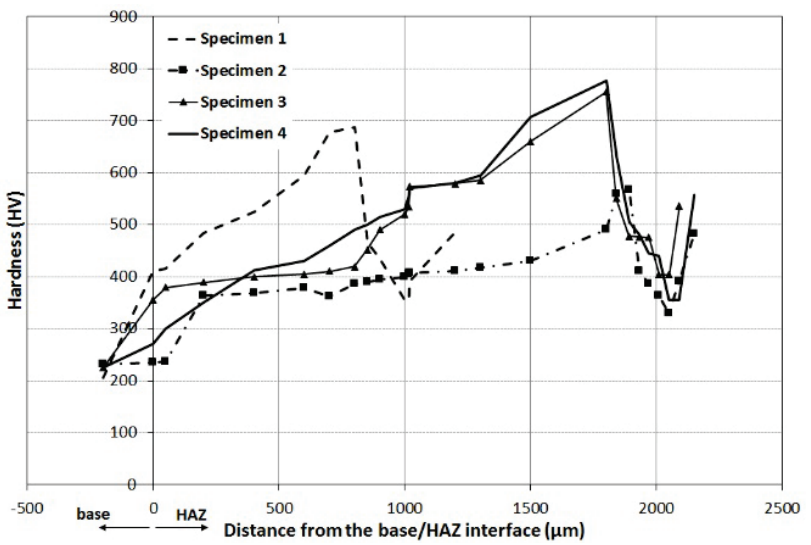

Figure 2Hardness in the heat affected zone

\section{Metallographic examination}

According to the phase diagram (Fig. 3), the solidification process of the OCR VM (W. Nr. 1.2739) steel starts with solidification of austenite, followed by eutectic solidification reaction of primary ledeburite $\left(\gamma_{\mathrm{Fe}}+\mathrm{M}_{7} \mathrm{C}_{3}\right)$. Final microstructure is composed of steel matrix and larger amount $(\approx 15 \%)$ of eutectic. Matrix microstructure depends on cooling rate and can change with decreasing cooling rate from martensite to bainite or pearlite. During slow cooling to room temperature, precipitation of secondary carbides $\left(\mathrm{M}_{7} \mathrm{C}_{3}, \mathrm{M}_{23} \mathrm{C}_{6}, \mathrm{M}_{3} \mathrm{C}\right.$, $\mathrm{M}_{2} \mathrm{C}, \mathrm{MC}$ ) occurs.

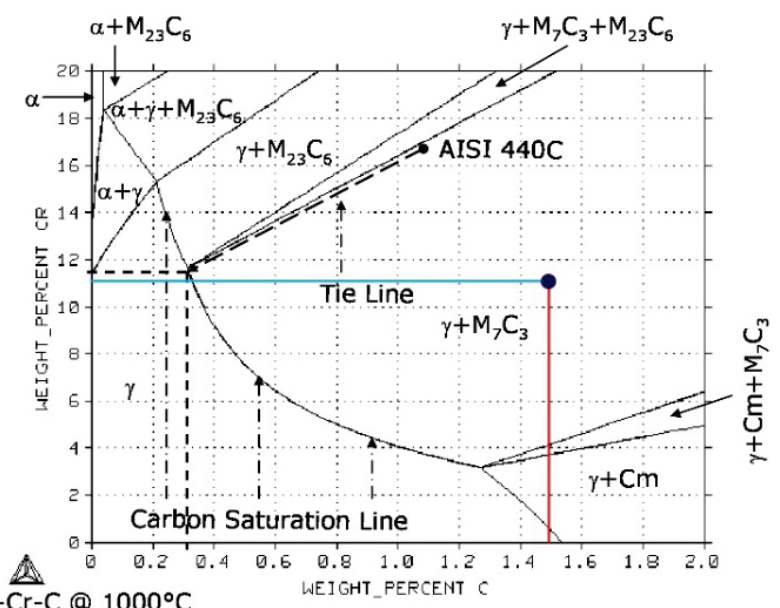

Fe-Cr-C @ $1000^{\circ} \mathrm{C}$

Figure 3 Isothermal section of phase diagramFe-Cr-C at $1000{ }^{\circ} \mathrm{C}[8]$

The most interesting change in the microstructure was the formation of secondary ledeburite in HAZ. Since the microstructure in the HAZ was similar for both Vjoint specimens, we documented only the microstructure of specimen 1. Fig. 4a shows the microstructure at the interface of the base material and cold part of HAZ, Fig. $4 \mathrm{~b}$ microstructure in the cold part of the HAZ and Fig. 4c microstructure in the hot part of the HAZ. Figs. 4d and Fig. 5 present microstructure at the interface between HAZ-hot part and the weld.

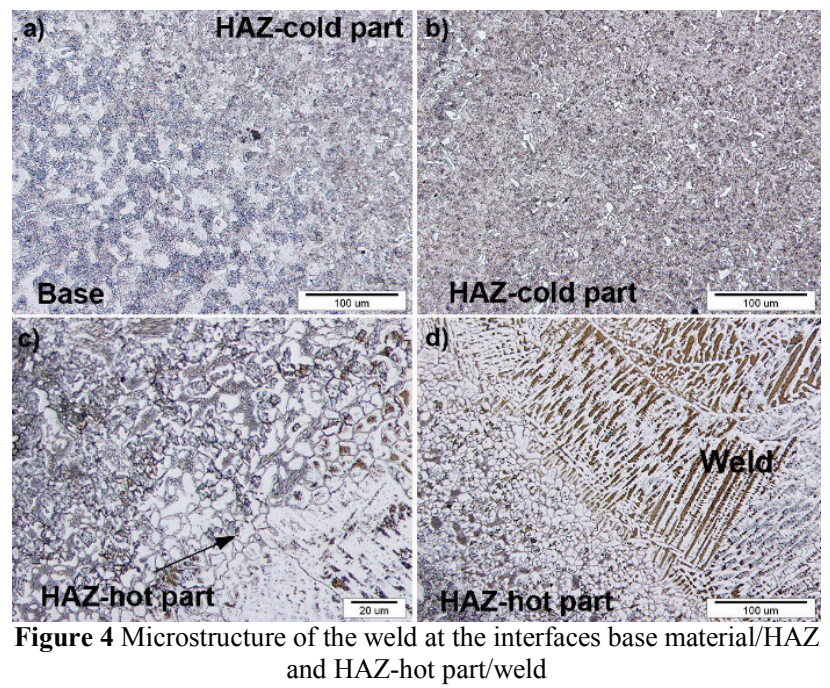

As can be seen form Figs. 4 and 5 the microstructure of the base material is composed of martensitic matrix and primary ledeburite $\left(\gamma_{\mathrm{Fe}}+\mathrm{M}_{7} \mathrm{C}_{3}\right)$. Fig. 6a shows microstructure with primary eutectic carbides at the base material/HAZ interface. The form of primary carbides already changes to a certain extent in the cold part of the HAZ (Fig. 6b), while in the hot part of HAZ, in the surrounding area of primary carbides, secondary ledeburite area, with its typical lamellar structure is visible (Fig. 6c). Larger secondary ledeburite areas were found only in HAZ-hot part. 


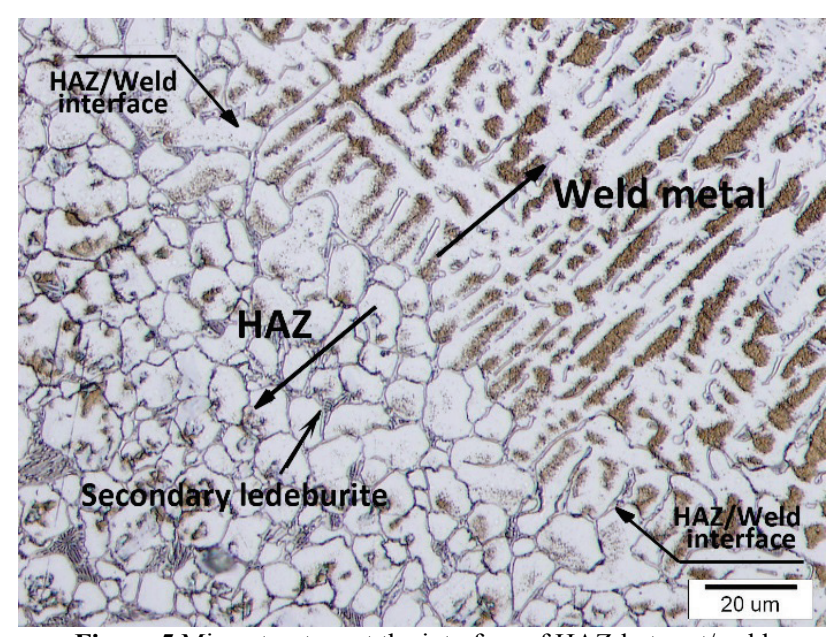

Figure 5 Microstructure at the interface of HAZ-hot part/weld

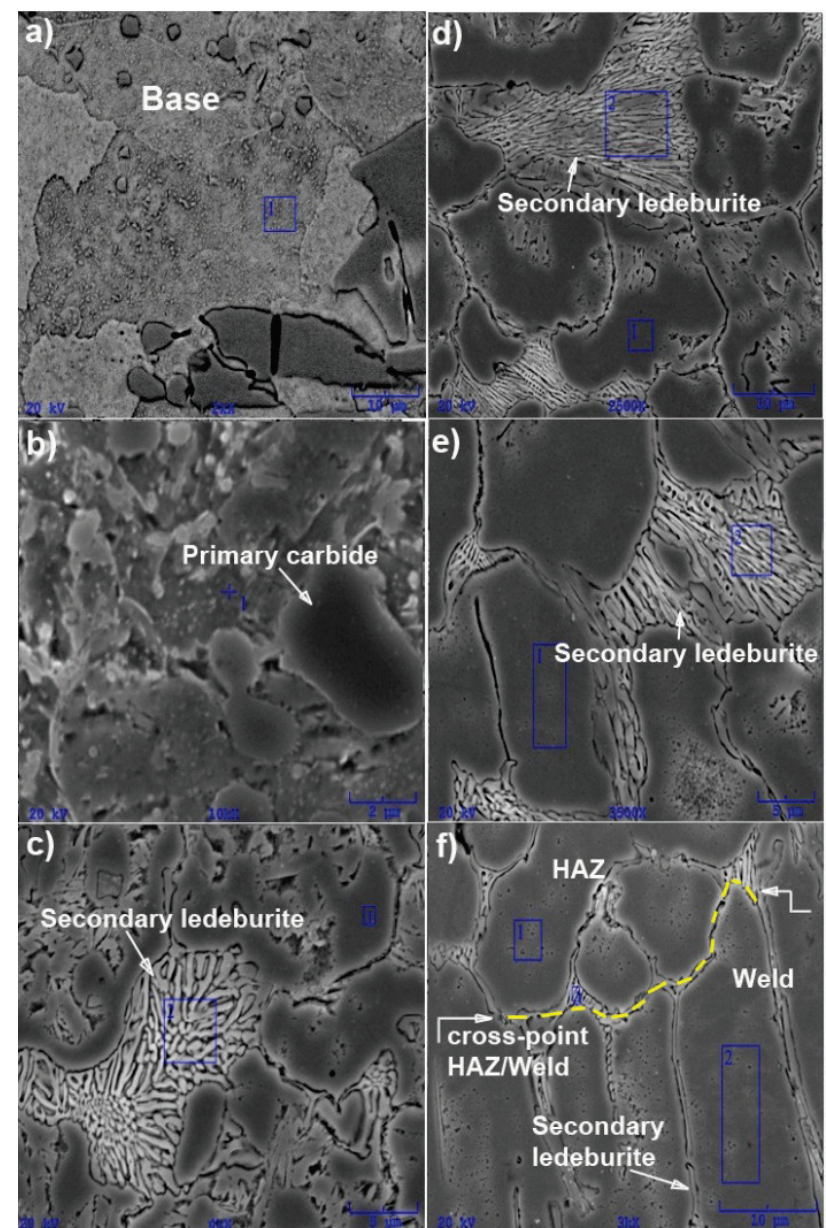

Figure6 a) Primary (eutectic) carbide in the base material,b) changed Primary carbide in the cold part of HAZ, c-f) secondary eutectic formation at various areas in the hot part of HAZ; SEM; SEI formed only at the matrix crystal grain boundaries in the HAZ. Secondary eutectic has multi-component chemical composition (Tab. 3, Fig. 7), and besides iron and carbon also contain $\mathrm{Cr}$, Mo and $\mathrm{V}$ alloying elements.

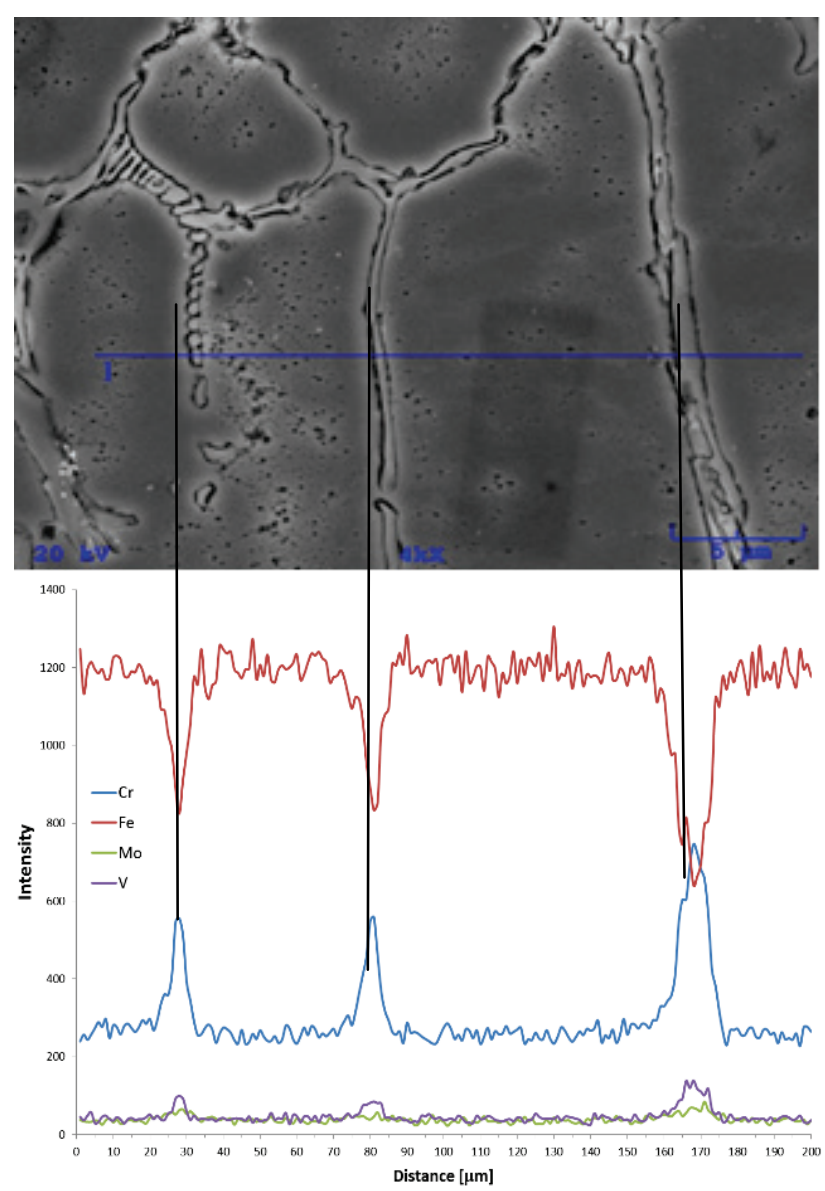

Figure 7 a) Microstructure in the hot part of HAZ, with secondary ledeburite on the borders of matrix grains (Specimen 1); SEM; SEI; b) Concentration profile of alloying elements over the crystal grains and secondary eutectic in the area of HAZ-hot part; EDXS

The microstructure in the HAZ was similar for both surfaced specimens. Fig. 8a shows the microstructure at the base material/HAZ-cold part interface, Fig. $8 \mathrm{~b}$ microstructure in the cold part of HAZ, Fig. 8c microstructure of the whole $\mathrm{HAZ}$ area, and Fig. $8 \mathrm{~d}$ microstructure at the $\mathrm{HAZ} /$ weld interface.

At the HAZ/weld interface secondary ledeburite was present only at the borders of the matrix crystal grains in the filer penetration zone, while larger secondary ledeburite areas where found in the hot part of HAZ (Fig. 9).

The size of secondary ledeburite areas and the distance between individual carbide lamelas increased in the direction of the weld (Figs. 6d and 6e). At the HAZ/weld metal interface, secondary ledeburite was

Table 3 Chemical composition of secondary ledeburite (without carbon)

\begin{tabular}{|l|c|c|c|c|c|c|}
\hline \multirow{2}{*}{ Point of analysis } & \multirow{2}{*}{ Microstructure } & \multicolumn{5}{|c|}{ Chemical composition (wt. \%) } \\
\cline { 3 - 7 } & & $\mathrm{Fe}$ & $\mathrm{Si}$ & $\mathrm{Cr}$ & $\mathrm{V}$ & Mo \\
\hline HAZ: cold/hot part & Ledeburite & 68,11 & 0,18 & 27,4 & 3,03 & 0,82 \\
\hline HAZ: hot part point 1 & Ledeburite & 71,5 & 0,14 & 23,8 & 2,9 & 1,7 \\
\hline HAZ: hot part point 2 & Ledeburite & 66,4 & 0,08 & 28,4 & 1,5 & 3,7 \\
\hline HAZ: hot part/weld & Ledeburite & 64,5 & 0,13 & 29,7 & 3,6 & 2,02 \\
\hline
\end{tabular}




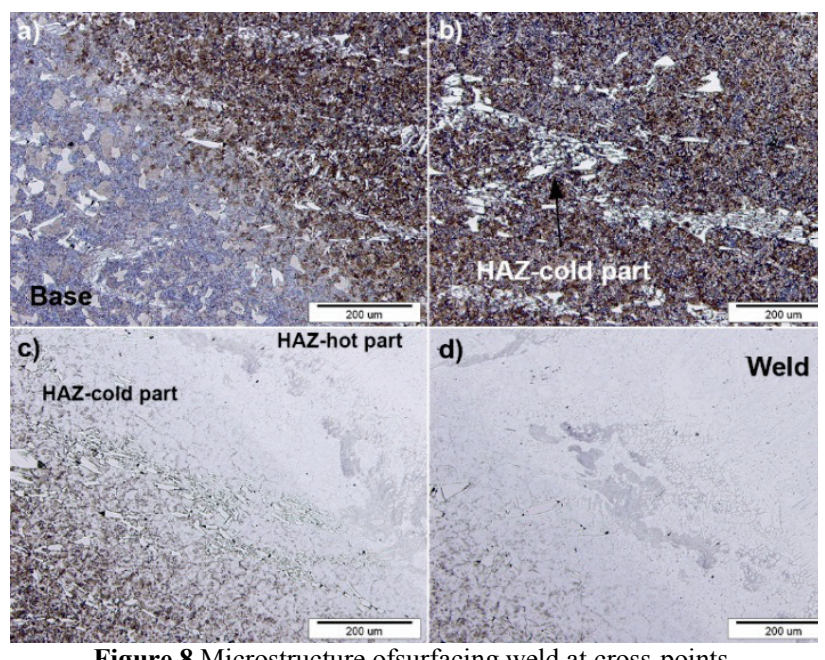

Figure 8 Microstructure ofsurfacing weld at cross-points base/HAZ/weld (Specimen 3, SAW surfacing)

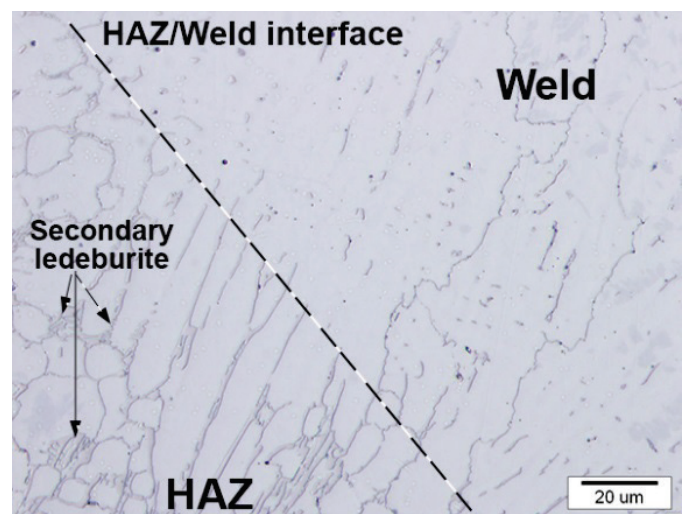

Figure 9 Microstructure at the HAZ/weld interface (SAW surfacing)
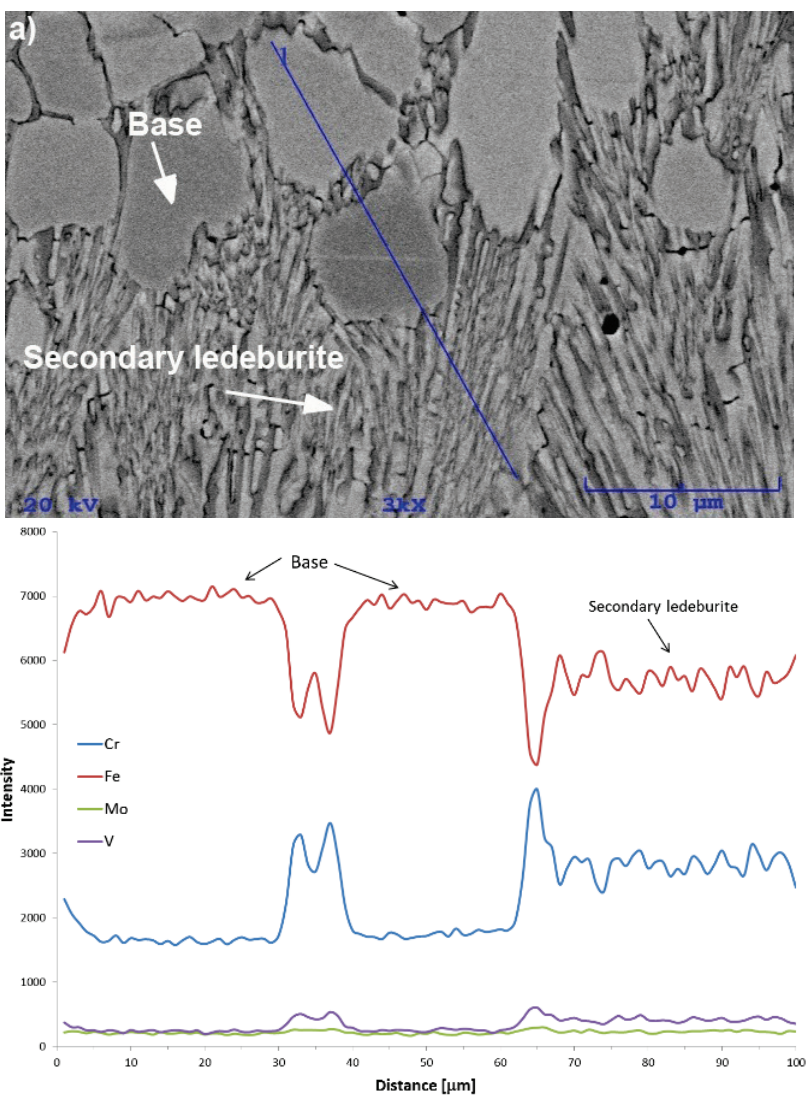

Figure 10 a) Microstructure of HAZ-hot part; SEM, SEI;

b) Concentration profile of alloying elements over the matrix grains and secondary ledeburite; EDXS, (specimen 4, SAW surfacing)
Measurement of element concentration profile across the matrix grains and secondary ledeburite areas (Fig. 10a) revealed increased concentration of alloying elements in the secondary ledeburite. Besides chromium content increase, also vanadium concentration increase can be seen (Fig. 10 b).

\section{Results}

Many factors have an effect on the quality of the weld, one of them being the technique of welding. Previous tests have shown that secondary ledeburite can be formed in the hot part of the heat affected zone (HAZ) [3] when MAG or MIG welding technique are applied. In this experimental work we were interested in what is happening in the HAZ when submerged arc welding technique (SAW) is used, because the temperatures are even higher comparing to MAG and MIG welding methods. In submerged arc welding of ledeburitic tool steel the base material is well remelted and enough heat is transfered into the workpieces to induce formation of heat affected zone (HAZ). Our study was concentrated on the mechanics behind formation of secondary ledeburite and its effect on the weld crystalization.

Examened tool steel W. Nr. 1.2379 (OCR12 VM) is a typical example of chromium ledeburitic steels. During solidification process, primary ledeburite solidifies in the form of continuous net around austenitic grains. Transformation of austenite is cooling rate dependant, and can transform into martensite, bainite or pearlite. Some small amount of retained austenite will be also present in the final microstructure. During reheating to elevated temperatures, precipitation of secondary carbides occurs. Because the mechanical properties of the steel are in close correlation with the size, type, morphology, amount and distribution of carbides as well as with the matrix grain size, the main tasks in manufacturing precedure are breaking the eutectic net and attainment of homogeneous distribution of secondary carbides.

Larger eutectic carbides, which are due to their similar rectangular morphology often designated as primary carbides, are formed through the process of conglomeration and subsequent growth of eutectic and secondary carbides during heating to elevated temperatures. Because their workability is limited at lower temperatures of forging, compared to the steel matrix, deformation process breaks and separates them into smaller individual pieces. Cracking is usually transversal to the main axis of the carbide [12]. Broken carbide segments separate due to plastic flow of the matrix $[13,14]$, which can mix the matrix and carbides on a micro level in such a way that the surrounding area of eutectic carbides is not austenite of eutectic composition, but primary austenite $[15,16]$. It should be noted that such primary carbides still behave in the similar manner as eutectic, with the same melting temperature $\left(\approx 1260{ }^{\circ} \mathrm{C}\right)$. Partial disolution of those carbides will lead to enrichement of surrounding austenitic area with carbon and chromium, causing the conditions for eutectic reaction and formation of secondary ledeburite. In areas where chemical 
composition of carbide surrounding remains eutectic, partial remelting of the eutectic takes place even faster.

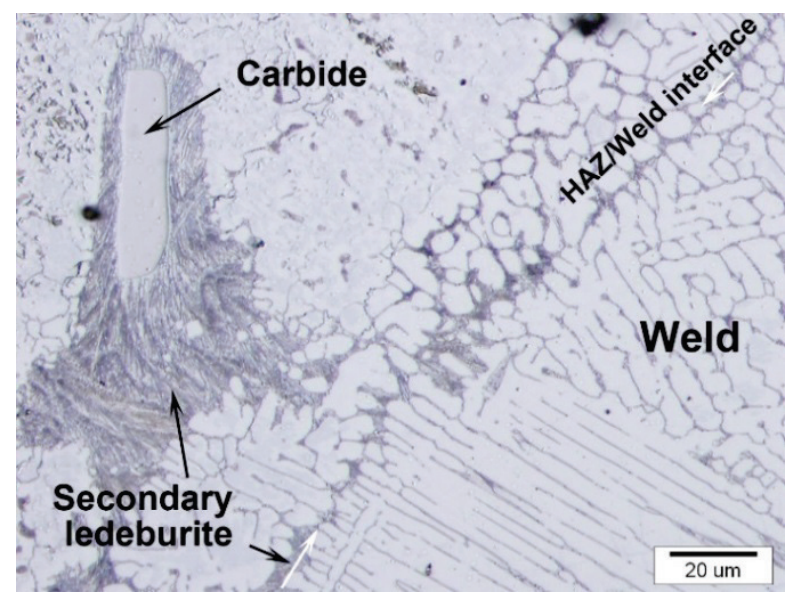

Figure 11 Microstructure at the HAZ/weld interface; partially dissolved primary carbide surrounded with secondary ledeburite

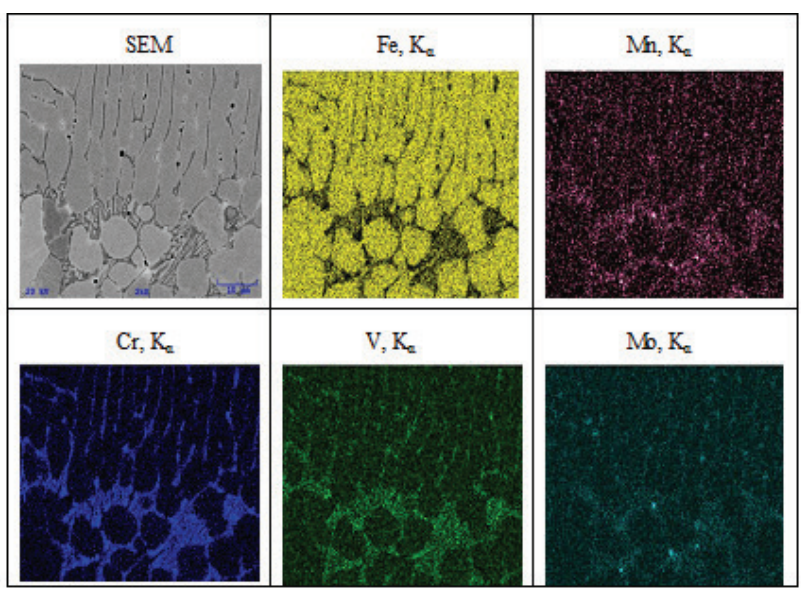

Figure 12 Specific distribution of iron, manganese, chromium, vanadium and molybdenenum at the HAZ/weld interface; SEM; EDXS; (Specimen 4; SAW surfacing)

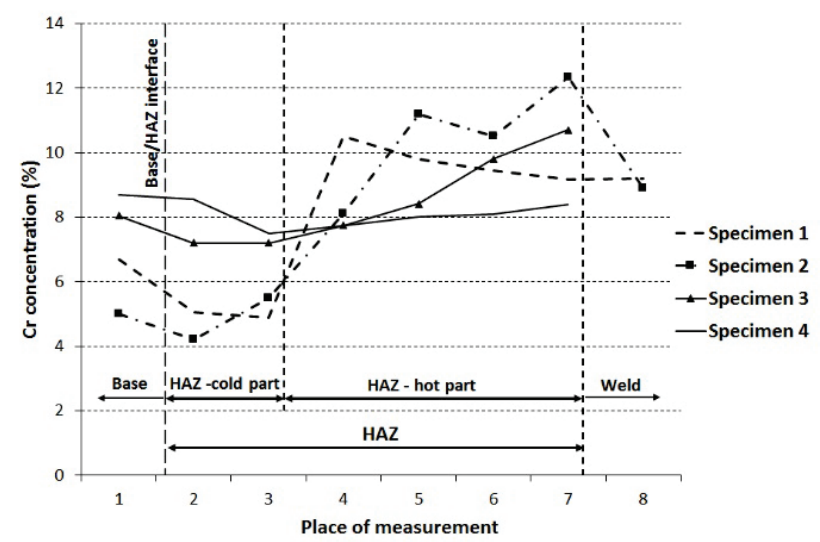

Figure 13 Change in concentration of chromium in the heat affected zone; SEM; EDXS

Fig. 11 shows an example of rounded partially dissolved primary carbide surrounded with larger area of secondary lamellar ledeburite. Secondary ledeburite is also present at the HAZ/weld interface and on matrix grain boundaries in HAZ. The specific distribution of elements (Fig. 12) reveals that beside chromium also manganese, vanadium and molybdenum are present in the secondary ledeburite. The results of EDXS point analysis of steel matrix arround larger carbides confirmed that concentration of chromium increases in the hot part of HAZ ((Fig. 13); place 4, 5, 6, 7).

\section{Conclusions}

The present article describes microstructural changes in the heat affected zone of ledeburitic tool steel W. Nr. 1.2379 (OCR12 VM) during welding or surfacing by submerged arc welding (SAW) technique.Formation of secondary ledeburite is a result of local remelting of the steel matrix around carbides, promoted by their partial or complete dissolution and diffusion of chromium and carbon into the surrounding matrix. During the welding process, temperature in the hot part of HAZ increased above $1300{ }^{\circ} \mathrm{C}$. This temperature is high enough to cause partial dissolution of carbides, diffusion of chromium and carbon into the surrounding matrix, its melting and subsequent formation of secondary ledeburite eutectic. The results show that higher energy input causes larger area of secondary ledeburite, which can be linked with wider heat affected zone and higher termperature in the hot part of HAZ. The use of input energy higher than nessesary should be avoided.

\section{References}

[1] Easterling, K. Introduction to the Physical Metallurgy of Welding. Butterworths \& Co Publishers, London, 1983.

[2] Kosec, G.; Arzenšek, B.; Vojvodič Tuma, J.; Vodopivec, F. The brittle tensile fracture and cleavage strength of a structural steel with a simulated weld-affected-zone microstructure. // Materials and Technology. 43, 1(2009), pp. 31-37.

[3] Hrivňák, I. Theory of weldability of metals and alloys. Elsevier, Amsterdam, 1992.

[4] Tonkovič Prijanovič, M.; Kosec, L. Heat affected zone in surfacing chromium ledeburitic steel. // Metallurgy. 49, 3(2009), pp. 155-160.

[5] Timmins, P. F. Fracture Mechanisms and Failure Control for Inspectors and Engineers. ASM International, Materials Park, Ohio, 1995.

[6] Jocić, B. Steels and Cast Irons, BIO-TOP d.o.o., Dobja Vas, 2008.

[7] Elektrode Jesenice d.o.o., Welding Consumables, Jesenice, 2011.

[8] ASM Handbook, Volume 9: Metallography and Microstructures. ASM International, Materials park, Ohio, 2009.

[9] ASM Handbook, Volume 8: Metallography, Structures and Phase Diagrams. ASM International, Materials park, Ohio, 2002.

[10] Jevremović, D. P.; Puškar, T. M.; Budak, I.; Vukelić, Đ.; Kojić, V.; Eggbeer, D.; Williams, R. J. An RE/RM approach to the design and manufacture of removable partial dentures with a biocompatibility analysis of the F75 Co-Cr SLM alloy. // Materials and Technology. 46, 2(2012), pp. 123-129.

[11] Kosec, G.; Nagode, A.; Budak, I.; Antić, A.; Kosec, B. Failure of the pinion from the drive of a cement mill. // Engineering Failure Analysis. 18, 1(2011), pp. 450-454.

[12] Tadić, B.; Jeremić, B.; Todorović, P.; Vukelić, Đ.; Proso, U.; Mandić, V.; Budak, I. Efficient workpiece clamping by indenting cone-shaped elements. // Journal of Precision Engineering and Manufacturing. 13, 10(2012), pp. 17251735 . 
[13] Zorc, B. Chemical and microstructural diversity of steel grades 355. // Revista de Metalurgia. 38, 6(2002), pp. 451456.

[14] Zorc, B. Automatic TIG welding of austenitic stainless steels in nitrogen and nitrogen-based gas mixtures.// Revista de Metalurgia. 47, 1(2011), pp. 29-37.

[15] Kosec, B.; Kosel, F.; Kosec, L.; Bizjak. M. Macroscopic modelling of two-phase metal materials subjected to plastic deformation. // Metallurgy. 40, 1(2001), pp. 29-32.

[16] Kosec, B.; Kovačević, D.; Kosec, L.; Kosel, F. Macroscopic modelling and FEA of tensile deformed twophase metal-matrix materials. // Journal of Production Engineering. 14, 1(2011), pp. 27-30.

\section{Authors' addresses}

Marica Prijanovič Tonkovič, dr. sc.

High Mechanical Engineering School,

Šegova ulica 112

8000 Novo mesto, Slovenia

E-mail: marica.prijanovic-tonkovic@guest.arnes.si

Alěs Nagode, dr. sc.

University of Ljubljana

Faculty of Natural Sciences and Engineering

Aškerčeva cesta 12

1000 Ljubljana, Slovenia

E-mail: ales.nagode@omm.ntf.uni-lj.si

Borut Kosec, prof. dr. sc.

University of Ljubljana

Faculty of Natural Sciences and Engineering

Aškerčeva cesta 12

1000 Ljubljana, Slovenia

E-mail: borut.kosec@omm.ntf.uni-lj.si

Ivan Samardžić, prof. dr. sc.

J. J. Strossmayer University of Osijek

Mechanical Engineering Faculty in Slavonski Brod

Trg Ivane Brlić Mažuranić 2

35000 Slavonski Brod, Croatia

E-mail: isamar@sfsb.hr

Blaž Karpe, dr. sc.

University of Ljubljana

Faculty of Natural Sciences and Engineering

Aškerčeva cesta 12

1000 Ljubljana, Slovenia

E-mail: blaz.karpe@omm.ntf.uni-lj.si

Ladislav Kosec, prof. dr. sc.

University of Ljubljana

Faculty of Natural Sciences and Engineering

Aškerčeva cesta 12

1000 Ljubljana, Slovenia

E-mail: ladislav.kosec@omm.ntf.uni-lj.si 